\title{
Insuficiência respiratória aguda na criança
}

\author{
Respiratory failure in children
}

Alessandra Kimie Matsuno

\begin{abstract}
RESUMO
Este texto apresenta uma revisão da definição, da fisiopatologia e do manejo das emergências respiratórias e da insuficiência respiratória aguda na criança, enfatizando os dispositivos mais adequados de liberação de oxigênio. As crianças são mais suscetíveis aos problemas respiratórios graves, sendo estes, causas importantes de procura pela sala de emergência em pediatria. O reconhecimento precoce e o início rápido de tratamento são pontos fundamentais para o melhor desfecho desses pacientes.

Palavras-chave: Insuficiência Respiratória. Criança. Serviço Hospitalar de Emergência. Dispositivos de Liberação de Oxigênio.
\end{abstract}

\section{Introdução}

Os problemas respiratórios são causas comuns de atendimento nas salas de emergência em todo mundo e constituem uma das principais causas de parada cardiorrespiratória em crianças, tanto em ambiente pré-hospitalar quanto hospitalar. Aproximadamente $2 / 3$ dos casos de insuficiência respiratória aguda acontecem no primeiro ano de vida. ${ }^{1}$

O reconhecimento precoce da insuficiência respiratória é de importância fundamental, uma vez que o desfecho após a parada respiratória é bem melhor do que após a parada cardíaca (70\% vs. $10 \%$ de sobrevida). Portanto, quanto mais cedo forem detectados os sinais de desconforto respiratório ou de insuficiência respiratória e quanto mais precoce o início da terapia apropriada, evitando-se evolu- ção para parada cardíaca, maiores serão as chances de sobrevivência. ${ }^{2,3}$

\section{Definições}

A insuficiência respiratória aguda é definida como a incapacidade do sistema respiratório de obter oxigênio $\left(\mathrm{O}_{2}\right)$ para suprir as necessidades teciduais e de eliminar dióxido de carbono $\left(\mathrm{CO}_{2}\right)$ proveniente do metabolismo celular. Caracteriza-se por hipoxemia, hipo/ normo ou hipercapnia e distúrbios do equilíbrio ácido-base. Define-se hipoxemia como uma pressão parcial de $\mathrm{O}_{2}$ em sangue arterial $\left(\mathrm{PaO}_{2}\right)<50 \mathrm{~mm} \mathrm{Hg}$ em recém-nascidos e $<60 \mathrm{~mm} \mathrm{Hg} \mathrm{em} \mathrm{crianças} \mathrm{maio-}$ res, e hipercapnia como $\mathrm{PaCO}_{2}>45 \mathrm{~mm} \mathrm{Hg}$, em qualquer idade. ${ }^{1}$
Professora Colaboradora do Departamento de Puericultura e Pediatria da Faculdade de Medicina de Ribeirão Preto da Universidade de São Paulo
Correspondência: Avenida dos Bandeirantes 3900 14049-900 / Ribeirão Preto - SP. matsuno@fmrp.usp.br

Artigo recebido em 11/04/2012 Aprovado para publicação em 20/06/2012 


\section{Particularidades pediátricas}

As crianças têm características anatômicas e fisiológicas que as predispõem ao desenvolvimento de insuficiência respiratória quando acometidas de patologias do sistema respiratório. Dentre elas, destacamse: ${ }^{1,2,4}$

1. A língua dos lactentes é maior em relação à orofaringe e a mandíbula é menor, em comparação com os adultos. Assim, a língua preenche grande parte da cavidade oral das crianças. Consequentemente, situações que levam à perda do tônus muscular e ao deslocamento posterior da língua podem causar obstrução grave de vias aéreas superiores em crianças.

2. A respiração é predominantemente nasal até o $4^{\circ}$ $6^{\circ}$ mês de idade. Assim, patologias que levam à obstrução nasal podem causar desconforto respiratório importante e crises de apneia, nesta faixa etária.

3. As vias aéreas em crianças possuem menor diâmetro e são mais curtas e em menor número do que em adultos. Como a resistência ao fluxo de ar é inversamente proporcional à quarta potência do raio da via aérea, reduções relativamente pequenas no diâmetro da via aérea resultam em aumento proporcionalmente maior da resistência ao fluxo de ar e do trabalho da respiração em crianças.

4. Em adolescentes e adultos, a porção mais estreita da via aérea é no nível das cordas vocais (rima glótica), e a laringe tem formato cilíndrico. Em crianças abaixo de 10 anos, a porção mais estreita da via aérea é abaixo das cordas vocais, no nível da cartilagem cricoide, e a laringe assume a forma de funil, devido ao tamanho relativamente menor da cartilagem cricoide em relação à cartilagem tireoide. Consequentemente, patologias que acometem a região subglótica, como as laringites virais, podem resultar em aumento importante da resistência ao fluxo de ar nesta região e insuficiência respiratória aguda, particularmente em crianças mais jovens.

5. A epiglote do lactente é mais longa e flácida do que a epiglote do adulto, e possui formato de "U" ou "V", projetando-se em ângulo de $45^{\circ}$ em relação à parede anterior da laringe. Neste local, projeta-se também a parte posterior da língua estreitando a retrofaringe e aumentando a resistência ao fluxo aéreo. Esta disposição anatômica das estruturas supraglóticas favorece a instalação de insuficiência respiratória precoce e grave em crianças acometidas de doenças que causam edema e inflamação da região (p. ex., epiglotite).
6. Em crianças, o menor suporte cartilaginoso da árvore traqueobrônquica a torna mais complacente e suscetível ao colapso dinâmico durante a inspiração, na presença de obstrução das vias aéreas.

7. A caixa torácica em crianças é mais complacente do que em adultos, em decorrência da consistência cartilaginosa dos ossos e menor desenvolvimento da musculatura respiratória. A maior complacência torácica resulta em necessidade de realizar maior esforço inspiratório para gerar volume corrente adequado.

8. Em recém-nascidos e lactentes, a caixa torácica é arredondada, com o diâmetro ântero-posterior igual ao transverso, devido à posição mais horizontal das costelas, quase perpendiculares à coluna vertebral. Com o crescimento, as costelas se tornam oblíquas, dirigindo-se para baixo e para frente. No final do primeiro ano de idade, o diâmetro transverso tornase maior que o ântero-posterior, adquirindo o formato elíptico do adulto, por volta dos 7 anos de idade. $\mathrm{O}$ formato arredondado do tórax confere desvantagem à mecânica respiratória de crianças pequenas, porque ocorre menor elevação das costelas durante a contração da musculatura intercostal. 9. A inserção do diafragma em crianças é mais horizontal e elevada (na altura da oitava e nona vértebras torácicas), enquanto que no adulto, o diafragma insere-se obliquamente, na altura da nona e décima vértebras torácicas. Consequentemente, em crianças, o movimento do diafragma é menor durante a inspiração, o que limita a expansibilidade da caixa torácica.

10. As crianças são mais suscetíveis à fadiga respiratória do que os adultos, porque possuem musculatura respiratória menos desenvolvida e frequência respiratória mais elevada.

11. As vias de ventilação colateral alveolar, como os poros intra-alveolares de Kohn e os canais bronquíolo-alveolares de Lambert, são menos desenvolvidas em crianças, o que facilita a formação de atelectasias, escape de ar de unidades semiobstruídas e hiperinsuflação pulmonar.

12. As crianças têm taxa metabólica mais alta e desta forma, consumo de oxigênio maior que os adultos (6-8 $\mathrm{mL} / \mathrm{kg} / \mathrm{min}$ vs $4 \mathrm{~mL} / \mathrm{kg} / \mathrm{min})$. Ao mesmo tempo, possuem menor capacidade residual funcional e menores reservas de oxigênio, que propiciam maiores chances de desenvolver hipoxemia e hipóxia tissular com maior rapidez quando ocorre qualquer alteração da respiração. 


\section{Fisiopatologia da insuficiência res- piratória aguda}

A função primária do sistema respiratório é fornecer $\mathrm{O}_{2}$ e remover $\mathrm{CO}_{2}$ do organismo. A respiração consiste na troca de gases entre o meio ambiente e as células (respiração externa), e na reação intracelular do $\mathrm{O}_{2}$ com moléculas orgânicas, com produção de $\mathrm{CO}_{2}$, água e ATP (respiração celular). A respiração externa requer a função integrada dos sistemas respiratório e cardiovascular. Clinicamente, a insuficiência respiratória se manifesta quando este sistema integrado falha em prover oxigenação adequadamente, evidenciada por baixa $\mathrm{PaO}_{2}$, ou quando ocorre falha da remoção de $\mathrm{CO}_{2}$, evidenciada pelo aumento da $\mathrm{PaCO}_{2} \cdot 1,5$

Didaticamente, a insuficiência respiratória pode ser classificada em dois tipos: insuficiência ventilatória e falência da oxigenação. A insuficiência ventilatória é definida pela retenção de $\mathrm{CO}_{2}$. $\mathrm{O} \mathrm{CO}_{2}$ é eliminado do corpo por meio das trocas gasosas nos pulmões, durante a expiração, sendo transferido através da membrana alvéolo-capilar por gradiente de pressão entre o sangue venoso misto $\left(\mathrm{PaCO}_{2} \sim 46 \mathrm{~mm} \mathrm{Hg}\right)$ e o alvéolo $\left(\mathrm{PCO}_{2} \sim 40 \mathrm{~mm} \mathrm{Hg}\right)$. Normalmente, a quantidade de $\mathrm{CO}_{2}$ eliminada pelos pulmões é igual à quantidade produzida pelo corpo, e diretamente proporcional à ventilação alveolar. ${ }^{5}$

A ventilação alveolar é a proporção de gás que entra e sai dos alvéolos e segue para as trocas com o sangue que passa pelos pulmões. É definida como o produto da frequência respiratória (FR) pelo volume corrente (VC) menos o volume do espaço morto (VD) (Equação 1).

Ventilação Alveolar = FR x $(\mathrm{VC}-\mathrm{VD})($ Equação 1)

A ventilação do espaço morto é definida como a quantidade de ar que não segue para as trocas gasosas com o sangue, porque permanece nas vias aéreas condutoras (espaço morto anatômico) ou atinge alvéolos não perfundidos (espaço morto alveolar). ${ }^{5}$

A retenção de $\mathrm{CO}_{2}$ pode ser causada por qualquer processo que diminua a ventilação minuto (diminuindo a frequência respiratória ou o volume corrente) ou que aumente a ventilação do espaço morto. Portanto, a hipercapnia pode ser causada por dois mecanismos: a hipoventilação ou o aumento da ventilação do espaço morto, que ocorre com o desequilíbrio ventilação-perfusão. ${ }^{1}$
A hipoventilação pura caracteriza-se por aumento da $\mathrm{PaCO}_{2}$ e diminuição da $\mathrm{PaO}_{2}$ e da pressão parcial de oxigênio alveolar $\left(\mathrm{PAO}_{2}\right)$, com gradiente alvéolo-arterial de $\mathrm{O}_{2}\left(\mathrm{D}(\mathrm{A}-\mathrm{a}) \mathrm{O}_{2}\right)$ normal $(5-20 \mathrm{~mm}$ $\mathrm{Hg}$ ) (Equação 2).

$$
\mathrm{D}(\mathrm{A}-\mathrm{a}) \mathrm{O}_{2}=\mathrm{PAO}_{2}-\mathrm{PaO}_{2}(\text { Equação 2) }
$$

Onde: $\mathrm{PAO}_{2}=\mathrm{PO}_{2}$ inspirado $-\mathrm{PCO}_{2 \text { alveolar }}$ Ou seja:

$\mathrm{PAO}_{2}=\mathrm{FiO}_{2} \times\left(\mathrm{P}_{\text {barométrica }}-\mathrm{P}_{\text {vapor } \mathrm{H}_{2} \mathrm{O}}\right)-\mathrm{PaCO}_{2}$ /quociente respiratório

A diminuição da ventilação minuto decorrente da diminuição da frequência respiratória ocorre em situações de depressão do sistema nervoso central por drogas, trauma, hemorragia e crises de apneia (particularmente em recém-nascidos e lactentes jovens). A diminuição da ventilação minuto causada pela diminuição do volume corrente ocorre em doenças neuromusculares, distúrbios metabólicos e patologias abdominais com aumento da pressão intra-abdominal. O aumento da ventilação do espaço morto ocorre em situações com desequilíbrio ventilação-perfusão, com ventilação proporcionalmente maior do que a perfusão, como por exemplo, nas doenças que levam à hiperinsuflação pulmonar, como a asma ou a bronquiolite, e em condições com comprometimento do fluxo sanguíneo pulmonar, como o tromboembolismo pulmonar. Normalmente, a proporção de ventilação do espaço morto em relação ao volume corrente (VD/ VC) é de $30 \%$ (Equação 3). O aumento da ventilação do espaço morto resulta em aumento do trabalho respiratório e, quando acima de $60 \%$, causa falência respiratória. ${ }^{1}$

VD/ VC $=\mathrm{PaCO}_{2}-$ Pet $\mathrm{CO}_{2} / \mathrm{PaCO}_{2}$ (Equação 3)

Onde:

Pet $\mathrm{CO}_{2}$ é a pressão de $\mathrm{CO}_{2}$ no ar exalado, medida pelo capnógrafo.

A falência da oxigenação resulta em hipoxemia e hipóxia tecidual. Os fatores que podem levar à hipoxemia, seus mecanismos fisiopatológicos e suas possíveis causas são listados na Tabela $1 .^{3}$

A baixa pressão parcial de oxigênio inspirado em regiões de alta altitude leva à hipoxemia, pois a pressão parcial de oxigênio alveolar $\left(\mathrm{PAO}_{2}\right)$ é diretamente proporcional à pressão barométrica (Equa- 


\section{Tabela 1}

Fatores, mecanismos fisiopatológicos e causas de hipoxemia.

\begin{tabular}{|c|c|c|}
\hline Fatores & Mecanismos & Causas \\
\hline Baixa $\mathrm{PO}_{2}$ ambiental & Diminuição da $\mathrm{PaO}_{2}$ & Altas altitudes \\
\hline Hipoventilação alveolar & Aumento da $\mathrm{PaCO}_{2}$ e diminuição da $\mathrm{PaO}_{2}$ & $\begin{array}{l}\text { Infecção do SNC } \\
\text { Trauma crânio-encefálico } \\
\text { Overdose de drogas }\end{array}$ \\
\hline Defeito da difusão & $\begin{array}{l}\text { Falha da troca de } \mathrm{O}_{2} \text { e } \mathrm{CO}_{2} \text { através da mem- } \\
\text { brana alvéolo-capilar, levando à diminuição } \\
\text { da } \mathrm{PaO}_{2} \text { e, tardiamente, aumento da } \mathrm{PaCO}_{2}\end{array}$ & $\begin{array}{l}\text { Proteinólise alveolar } \\
\text { Fibrose pulmonar } \\
\text { Pneumonia intersticial }\end{array}$ \\
\hline $\begin{array}{l}\text { Desequilíbrio ventilação (V)/ per- } \\
\text { fusão (Q) }\end{array}$ & $\begin{array}{l}\text { Áreas não ventiladas, mas com perfusão } \\
\text { adequada, resultando em diminuição da } \\
\mathrm{PaO}_{2} \text {, e em menor extensão, aumento da } \\
\mathrm{PaCO}_{2}\end{array}$ & $\begin{array}{l}\text { Pneumonia } \\
\text { SDRA } \\
\text { Edema pulmonar } \\
\text { Atelectasia } \\
\text { Asma, bronquiolite }\end{array}$ \\
\hline Shunt & $\begin{array}{l}\text { Mistura de sangue arterializado e venoso } \\
\text { no lado esquerdo do coração }\end{array}$ & $\begin{array}{l}\text { Shunt intracardíaco (cardiopatia congê- } \\
\text { nita cianosante) } \\
\text { Shunt extracardíaco (pulmonar) - as mes- } \\
\text { mas do desequilíbrio V/Q }\end{array}$ \\
\hline Alteração do transporte de $\mathrm{O}_{2}$ & $\begin{array}{l}\text { Diminuição do débito cardíaco e/ ou do } \\
\text { conteúdo arterial de } \mathrm{O}_{2}\end{array}$ & $\begin{array}{l}\text { Choque } \\
\text { Anemia } \\
\text { Intoxicação por CO } \\
\text { Metahemoglobinemia }\end{array}$ \\
\hline
\end{tabular}

Legenda: SNC = sistema nervoso central; SDRA = síndrome do desconforto respiratório agudo; CO = monóxido de carbono.

ção 2). Portanto, em regiões localizadas muito acima do nível do mar, $\mathrm{a} \mathrm{PAO}_{2}$ é mais baixa, podendo causar hipoxemia. ${ }^{1,6}$

Nos distúrbios da difusão decorrentes do aumento da espessura da barreira alvéolo-capilar, ocorre hipoxemia, com aumento da $\mathrm{D}(\mathrm{A}-\mathrm{a}) \mathrm{O}_{2}$. Como o $\mathrm{CO}_{2}$ é aproximadamente 20 vezes mais difusível que o oxigênio, a $\mathrm{PaCO}_{2}$ pode estar normal. ${ }^{3}$

O desequilíbrio ventilação-perfusão, caracterizado por unidades alveolares pouco ventiladas, mas com perfusão normal (ou quase normal), causa hipoxemia, pois não há trocas gasosas nas unidades alvéolo-capilares mal ventiladas. Portanto, o sangue venoso que retorna destas unidades tem baixa saturação de $\mathrm{O}_{2}$, levando à mistura de sangue arterializado e venoso no lado esquerdo do coração (efeito shunt). Nestas situações, a $\mathrm{D}(\mathrm{A}-\mathrm{a}) \mathrm{O}_{2}$ está aumentada, porém o shunt não eleva significativamente a $\mathrm{PaCO}_{2}$. $\mathrm{Na}$ maioria das vezes, a $\mathrm{PaCO}_{2}$ está normal, porque ocorre aumento da ventilação alveolar decorrente da estimulação dos quimiorreceptores pela hipóxia, com consequente eliminação de $\mathrm{CO}_{2}$ pelas unidades alveolares ventiladas. Deve-se ressaltar que em quadros obstrutivos de vias aéreas inferiores (asma e bronquiolite), a distribuição da ventilação pelos pulmões é bastante heterogênea, podendo ocorrer tanto aumento do espaço morto causado por hiperinsuflação quanto efeito shunt em áreas com atelectasia. ${ }^{1,4}$

Normalmente, o shunt fisiológico total é de 3 a $5 \%$ do débito cardíaco, e corresponde à fração do débito cardíaco que passa do sangue venoso misto para o sangue arterial sem ser oxigenado. De maneira simplificada, o shunt (Qs/ Qt) pode ser calculado pela Equação 4. O shunt é considerado leve quando $<15 \%$, moderado de 15 a $25 \%$, e grave $>25 \% .^{5}$

$$
\mathrm{Qs} / \mathrm{Qt}=\mathrm{D}(\mathrm{A}-\mathrm{a}) \mathrm{O}_{2} / 20 \text { (Equação 4) }
$$

As condições clínicas associadas à diminuição do débito cardíaco (p. ex. , choque) ou do conteúdo arterial de oxigênio $\left(\mathrm{CaO}_{2}\right)$ (p. ex. , anemia) alteram o 
transporte de oxigênio $\left(\mathrm{DO}_{2}\right)$ (Equação 5) e podem causar hipóxia tissular.

$$
\mathrm{DO}_{2}=\text { Débito cardíaco } \times \mathrm{CaO}_{2}(\text { Equação 5) }
$$

\section{Onde:}

$\mathrm{CaO}_{2}=$ Concentração de hemoglobina $(\mathrm{g} / \mathrm{dL}) \times 1,34$ $x \mathrm{SaO}_{2}+\left(\mathrm{PaO}_{2}\right.$ x 0,003$)$

Os fatores que influenciam a saturação arterial de oxigênio pelo desvio da curva de dissociação da oxihemoglobina para a esquerda, aumentando a afinidade do oxigênio pela hemoglobina, levam à diminuição da liberação de oxigênio aos tecidos e hipóxia tecidual, como a intoxicação por monóxido de carbono (inalação de fumaça) e a metahemoglobinemia. $\mathrm{O}$ monóxido de carbono apresenta maior afinidade pela hemoglobina que o oxigênio, deslocando a ligação do oxigênio à hemoglobina por competição. A metahemoglobina não transporta oxigênio e desvia a curva de dissociação da oxihemoglobina para a esquerda, diminuindo a liberação de oxigênio aos tecidos.

As causas de insuficiência respiratória estão listadas na Tabela 2., 6

As patologias obstrutivas levam ao aumento do trabalho respiratório pelo aumento da resistência das vias aéreas. A resistência é definida como a variação de pressão transpulmonar $(\Delta \mathrm{P})$ necessária para produzir fluxo de gás através das vias aéreas aos pulmões (Equação 6), sendo diretamente proporcional ao comprimento e inversamente proporcional à quarta potência do raio da via aérea (Equação 7). Portanto, a diminuição do diâmetro da via aérea pela metade aumenta 16 vezes a resistência. ${ }^{7}$

$$
\text { Resistência }=\Delta \mathrm{P} / \text { fluxo (Equação 6) }
$$

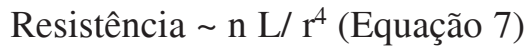

\section{Onde:}

n é a viscosidade do gás, L é o comprimento, e r é o raio da via aérea.

Ressalta-se que durante a respiração normal, o fluxo de entrada de ar nos pulmões é laminar. Quando ocorre turbulência do fluxo de ar, a resistência é maior, sendo inversamente proporcional à quinta potência do raio da via aérea. Desta forma, os pacientes agitados com fluxo de entrada de ar nos pulmões rápido e turbulento têm resistência muito maior do que aqueles com fluxo laminar, e, portanto, em situações de obstrução de vias aéreas é importante manter o paciente calmo para evitar turbulência do fluxo e aumento do trabalho da respiração. ${ }^{4}$

As patologias pulmonares restritivas e o aumento da pressão intra-abdominal levam à diminui-

\section{Tabela 2}

Causas de insuficiência respiratória

Depressão do centro respiratório

- Drogas (sedativos, anestésicos)

- Encefalopatia hipóxico-isquêmica

- Trauma crânio-encefálico

- Infecções (meningites, encefalites)

Doenças neuromusculares

- Síndrome de Guillain-Barré

- Miastenia Gravis

\section{Distúrbios metabólicos}

- Hipofosfatemia

- Hipomagnesemia

- Hipopotassemia

- Alcalose metabólica grave

\section{Bloqueio neuromuscular por drogas}

Patologias obstrutivas de vias aéreas

- Obstrução de vias aéreas superiores

- Laringite

- Epiglotite

- Corpo estranho

- Obstrução de vias aéreas inferiores

- Asma brônquica

- Bronquiolite

- Compressão extrínseca

Patologias restritivas do parênquima pulmonar

- Fibrose pulmonar

- Cifoescoliose

\section{Diminuição da complacência pulmonar}

- Edema pulmonar

- Pneumonia

- Síndrome do Desconforto Respiratório Agudo

- Doença da membrana hialina

Patologias abdominais

- Aumento da pressão intra-abdominal e elevação do diafragma

- Ascites volumosas

- Tumores abdominais

- Hemorragia intra-abdominal

- Obstrução do trato gastrintestinal

\section{Diminuição do transporte de $\mathrm{CO}_{2}$}

- Choque 
ção da complacência pulmonar e/ou da caixa torácica. A complacência é a capacidade de estiramento dos pulmões e da caixa torácica, definida como variação de volume $(\Delta \mathrm{V})$ por unidade de variação de pressão transmural $(\Delta \mathrm{P})$ (Equação 8$)$. Os pulmões com alta complacência expandem-se facilmente. Por outro lado, os pulmões com baixa complacência são “duros” e, portanto, mais esforço é necessário para insuflar os alvéolos. ${ }^{1}$

\section{Complacência $=\Delta \mathrm{V} / \Delta \mathrm{P}($ Equação 8$)$}

\section{Quadro clínico da insuficiência res- piratória aguda}

A frequência respiratória geralmente está aumentada (taquipneia) e pode-se observar aumento do esforço respiratório, com batimento de asas do nariz, tiragem intercostal, supra/ sub-esternal, supraclavicular, subcostal, contração da musculatura acessória da respiração e movimento paradoxal do abdome. A diminuição da frequência respiratória (bradipneia) e o aparecimento de ritmo respiratório irregular são sinais de alerta para a deterioração das condições clínicas da criança. Gemidos expiratórios sinalizam colapso alveolar e de pequenas vias aéreas, pois, na tentativa de aumentar a capacidade residual funcional e melhorar a oxigenação, a criança fecha a glote na expiração, emitindo gemidos. O estridor inspiratório e as alterações da voz sugerem obstrução das vias aéreas superiores (extratorácicas). Sibilos e aumento do tempo expiratório ocorrem nas patologias obstrutivas das vias aéreas inferiores (asma e bronquiolite) e no edema pulmonar. Podem ser observadas alterações na expansibilidade torácica na presença de efusões pleurais, pneumotórax, atelectasia, aspiração de corpo estranho e paralisia diafragmática. A ausculta de murmúrio vesicular diminuído com estertores crepitantes sugere pneumonia ou edema pulmonar. A diminuição ou abolição do murmúrio vesicular ocorre no derrame pleural, pneumotórax, atelectasia e obstrução de vias aéreas. Palidez cutânea e cianose central sinalizam hipoxemia, res- saltando-se que o aparecimento de cianose requer aproximadamente $5 \mathrm{~g} / \mathrm{dL}$ de hemoglobina reduzida e, portanto, a cianose pode não aparecer em crianças anêmicas. A diminuição do nível de consciência e do tônus muscular são sinais tardios associados à fadiga, e ocorrem em fases mais avançadas da insuficiência respiratória aguda. ${ }^{3}$

\section{Avaliação laboratorial e monitori- zação}

A gasometria arterial permite avaliar a eficácia da oxigenação e da ventilação, quantificar acidose respiratória ou metabólica, e monitorar a resposta à terapêutica. Os dados gasométricos podem ser utilizados para classificar a insuficiência respiratória, de acordo com sua evolução temporal (Figura 1). Na fase inicial (fase I), o organismo sob influência do processo mórbido começa a apresentar queda da $\mathrm{PaO}_{2}$. A seguir (fase II), o paciente apresenta aumento do volume minuto respiratório, o que evita quedas maiores da $\mathrm{PaO}_{2}$ e causa diminuição da $\mathrm{PaCO}_{2}$. Na fase III, apesar do aumento do trabalho respiratório, $\mathrm{a} \mathrm{PaO}_{2}$ diminui progressivamente e a $\mathrm{PaCO}_{2}$ volta ao "normal", ou seja, eleva-se gradativamente, pois o esforço respiratório foi superado. A fase IV caracteriza-se pela falência respiratória, com aumento progressivo da $\mathrm{PaCO}_{2}$ e diminuição gradual da $\mathrm{PaO}_{2}$ decorrentes de fadiga muscular. ${ }^{1}$

A oximetria de pulso permite avaliar continuamente a saturação arterial de oxigênio. Porém, o oxímetro de pulso requer fluxo sanguíneo pulsátil para

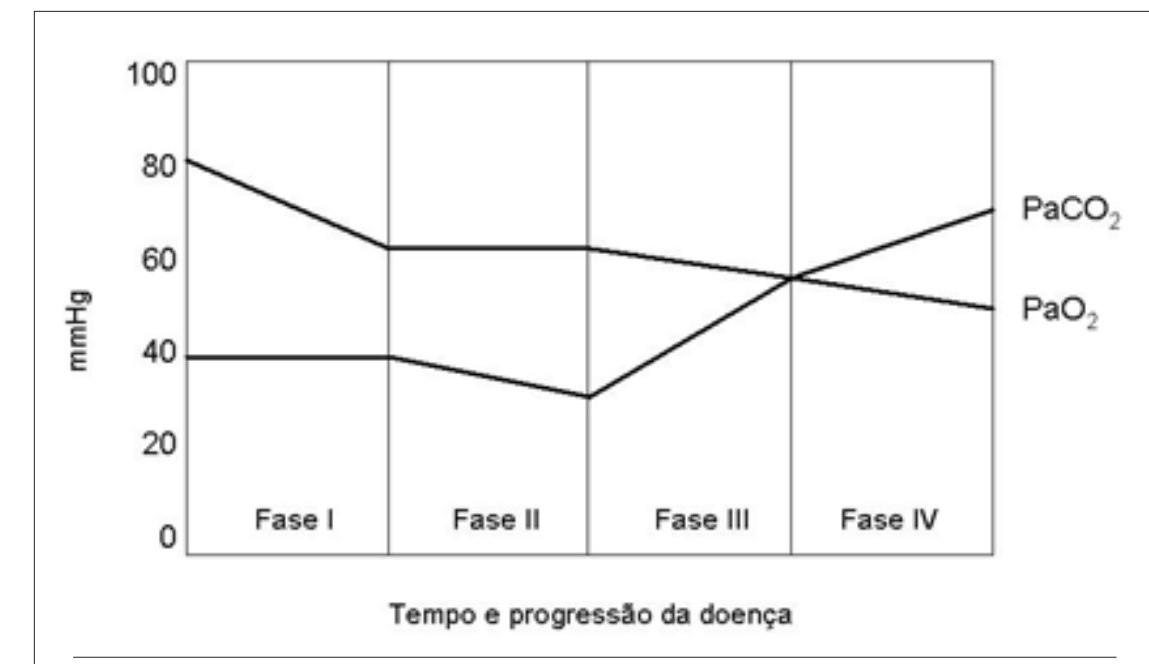

Figura 1: Evolução da $\mathrm{PaO}_{2}$ e da $\mathrm{PaCO}_{2}$ de acordo com a progressão da insuficiência respiratória. 
determinar a saturação de oxigênio e pode ser impreciso na presença de choque e de má perfusão tecidual, por vasoconstricção intensa nas extremidades. Além disso, a oximetria de pulso não reflete a saturação total da hemoglobina normal em situações de metahemoglobinemia ou carboxihemoglobinemia. ${ }^{8}$

A monitorização do $\mathrm{CO}_{2}$ exalado pode ser útil para confirmar a posição do tubo traqueal e estimar a $\mathrm{PaCO}_{2}$, em situações em que não há obstrução de vias aéreas ou desequilíbrio ventilação-perfusão nos pulmões. $\mathrm{O} \mathrm{CO}_{2}$ exalado pode ser monitorado por dispositivos quantitativos (capnografia), que medem a concentração de $\mathrm{CO}_{2}$ usando detectores infravermelhos de absorção, ou por dispositivos qualitativos, que se baseiam na reação química entre o $\mathrm{CO}_{2}$ exalado e um detector químico impregnado em uma tira de papel. Na presença de $\mathrm{CO}_{2}$, haverá mudança da cor do dispositivo, em que a cor roxa significa ausência de $\mathrm{CO}_{2}$ e a amarela, presença de $\mathrm{CO}_{2}$. A capnografia quantitativa permite a monitorização do $\mathrm{CO}_{2}$ exalado de forma contínua através do formato de onda quadrada durante o ciclo respiratório. ${ }^{2}$

\section{Tratamento Iniclal da Insufl- ciêncla respiratória}

O objetivo principal do tratamento é restaurar a oxigenação e a ventilação adequadas. Salienta-se que o reconhecimento precoce dos sinais de insuficiência respiratória e o início rápido do tratamento propiciam a melhor evolução do paciente. A intervenção inicial baseia-se na avaliação pediátrica rápida e dirigida, com o objetivo de classificar o tipo e a gravidade do problema respiratório, e depois, a cada intervenção, deve-se reavaliar o paciente. $\mathrm{O}$ tratamento inicial envolve a permeabilização das vias aéreas, a oxigenioterapia e a ventilação assistida, a manutenção da circulação adequada pela fluidoterapia e uso de drogas vasoativas (quando indicado), a otimização do transporte de oxigênio pela transfusão de concentrado de hemácias (se necessário), o tratamento da doença de base (p. ex. , antibioticoterapia para as causas infecciosas, correção dos distúrbios hidroeletrolíticos e metabólicos, etc.), a fisioterapia e o suporte nutricional. ${ }^{9}$

\section{Permeabilização das vias aéreas}

- Posicionamento: Pode ocorrer obstrução de vias aéreas pelo posicionamento inadequado da cabeça devido à flexão do pescoço e, em crianças sonolentas ou inconscientes, em decorrência de relaxamento da mandíbula, deslocamento posterior da língua em direção à parede posterior da faringe e colapso da hipofaringe. Por isso, é importante que se posicione corretamente a cabeça da criança, de forma a alinhar os eixos oral, traqueal e faríngeo. Esta posição é adquirida colocando-se um coxim embaixo dos ombros (crianças < 2 anos) para evitar flexão do pescoço ou um coxim abaixo do occipício (a partir de 2 anos), alinhando-se a parte anterior do ombro com o meato auditivo (Figuras $2 \mathrm{a}$ e 2b). ${ }^{2,3}$

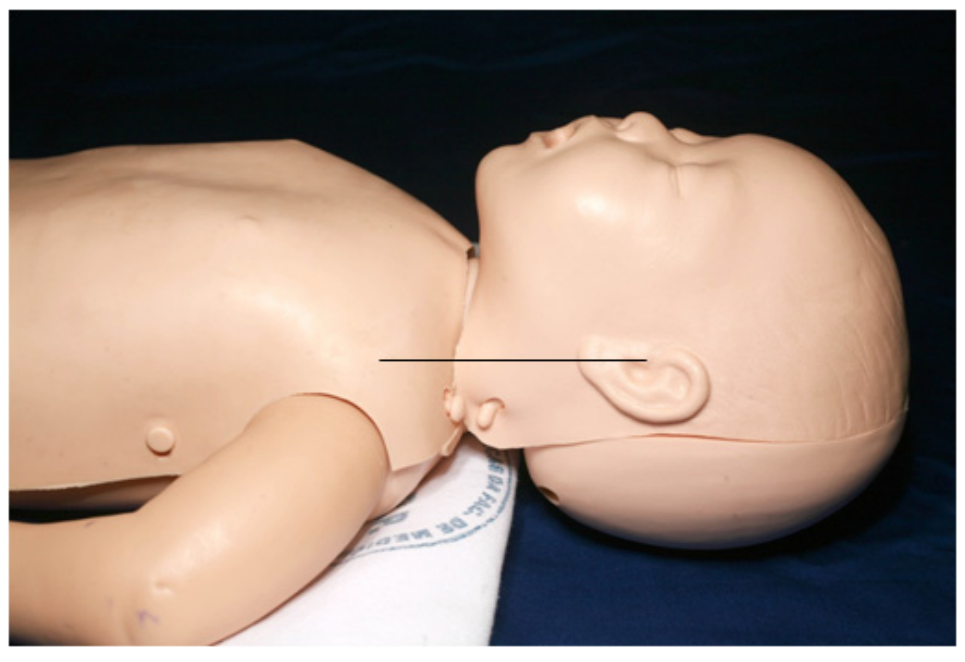

Figura 2a: Posicionamento da cabeça em criança menor de dois anos. Note o alinhamento entre o meato auditivo e a parte anterior do ombro.

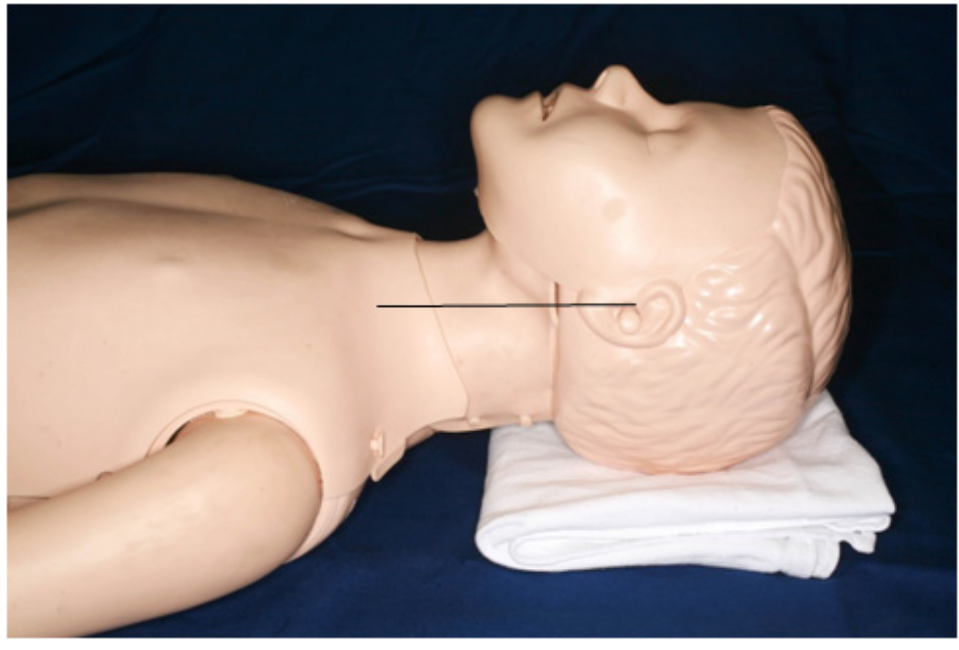

Figura 2b: Posicionamento da cabeça em criança maior de dois anos. Note o alinhamento entre o meato auditivo e a parte anterior do ombro. 
- Aspiração: Se necessário, deve-se fazer a limpeza das vias aéreas por meio da aspiração de secreção, muco ou sangue.

- Abertura das vias aéreas: Realiza-se a abertura das vias aéreas com manobra manual de inclinação da cabeça e elevação do queixo (Figura 3). Se houver suspeita de lesão de coluna cervical, deve-se elevar a mandíbula, sem inclinação da cabeça (Figura 4); caso esta manobra não seja efetiva, pode-se fazer uma leve extensão da cabeça, pois a abertura das vias aéreas é prioridade. ${ }^{2,3}$

- Dispositivos adicionais: Quando as manobras anteriores não são efetivas, podem ser utilizados dispositivos que ajudam a permeabilizar as vias aéreas, tais como a cânula orofaríngea e a cânula nasofaríngea.

\section{- Cânula orofaríngea ou de Guedel:}

Pode ser usada em pacientes inconscientes e serve para aliviar a obstrução causada pela língua. A cânula deve ser de tamanho adequado, ou seja, deve preencher a distância desde o canto da boca até a porção cefálica do ângulo da mandíbula. Se a cânula for muito comprida, a ponta se localizará posteriormente ao ângulo da mandíbula e obstruirá a abertura glótica, empurrando a epiglote para baixo. Ao contrário, se for muito pequena, a ponta se localizará bem acima do ângulo da mandíbula e exacerba-

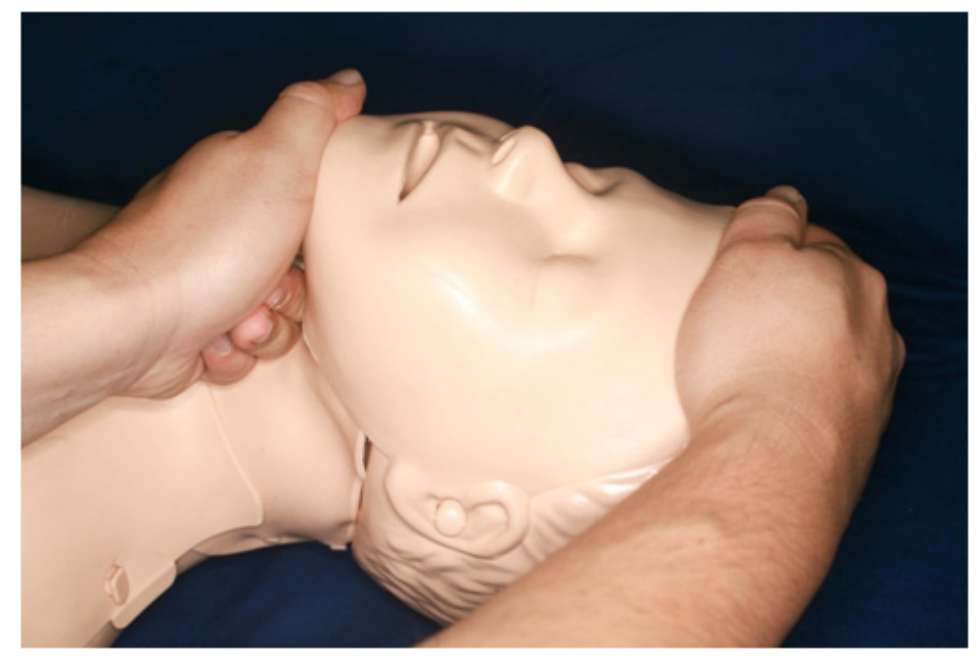

Figura 3: Abertura das vias aéreas pela inclinação da cabeça e elevação do queixo.

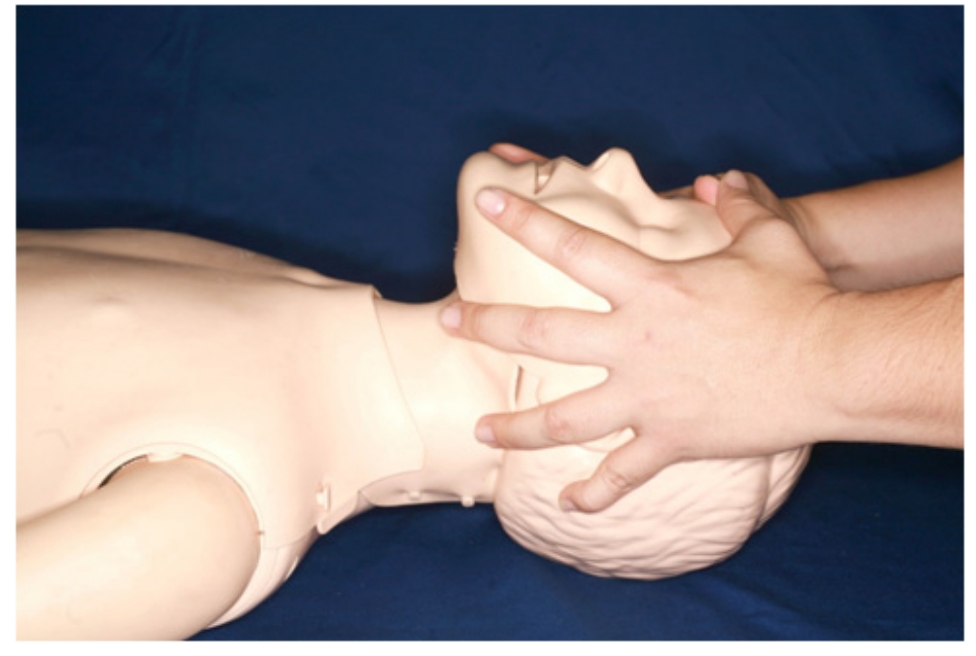

Figura 4: Abertura das vias aéreas pela elevação da mandíbula. rá a obstrução das vias aéreas, empurrando a língua em direção à hipofaringe. A cânula deve ser inserida enquanto um abaixador de língua contém a língua no assoalho da boca. ${ }^{2,6}$

- Cânula nasofaríngea: Pode ser usada em crianças conscientes, com reflexo de tosse intacto, e em crianças com comprometimento do nível de consciência apresentando diminuição do tônus faríngeo ou da coordenação, que causam obstrução das vias aéreas superiores. O tamanho adequado do comprimento da cânula é aproximadamente a distância entre a ponta do nariz até o lóbulo da orelha, e seu diâmetro externo não deve ser volumoso a ponto de empalidecer as aletas nasais. Um tubo traqueal encurtado pode ser usado como cânula nasofaríngea; a vantagem desta

adaptação é que sua maior rigidez serve para manter a permeabilidade das vias aéreas mesmo quando há hipertrofia de adenoides, mas ao mesmo tempo, pode haver trauma de tecidos moles durante a sua passagem. A colocação da cânula é feita após lubrificá-la, inserindo-a em direção posterior perpendicular ao plano da face, de maneira gentil, pois pode irritar a mucosa ou lacerar o tecido adenoideano e causar sangramento ao longo do assoalho da nasofaringe. Se a cânula for muito comprida, pode haver bradicardia por estímulo vagal durante sua inserção, ou lesão de epiglote ou de cordas vocais. Além disso, a irritação da laringe ou da faringe pode estimular a tosse e provocar vômitos ou laringoespasmo. ${ }^{6}$ 


\section{Oxigenação e ventilação}

- Oferta de oxigênio: A oferta e a demanda de oxigênio estão comprometidas em qualquer situação de enfermidade grave (p. ex., insuficiência respiratória, choque ou trauma). Portanto, nestas situações, deve-se sempre fornecer oxigênio após a permeabilização das vias aéreas. Quando se administra oxigênio a uma criança consciente, ela pode agitar com a colocação de dispositivos sobre a face, como cânulas ou máscaras, e desta forma, piorar o desconforto respiratório. Se isso ocorrer, deve-se colocar a criança em posição confortável junto aos pais ou, eventualmente, trocar a técnica de fornecimento de oxigênio. Se as vias aéreas estiverem pérvias e a ventilação espontânea for efetiva, podese administrar oxigênio por meio de numerosos dispositivos. A escolha do sistema de oferta de $\mathrm{O}_{2}$ é determinada pelo estado clínico da criança e pela concentração desejada de oxigênio. ${ }^{2,9}$

- Dispositivos de fornecimento de oxigênio: Podem ser divididos em sistemas de baixo fluxo e de alto fluxo.

\section{Sistemas de baixo fluxo:}

- Máscara simples de oxigênio: Fluxos de $\mathrm{O}_{2}$ de 6 a $10 \mathrm{~L} / \mathrm{min}$ fornecem $35-60 \%$ de oxigênio, devido à entrada de ar pelos orifícios laterais de escape (aberturas de exalação). A concentração será reduzida se a necessidade de fluxo inspiratório for alta, a máscara estiver solta ou o fluxo fornecido for muito baixo. ${ }^{2}$

- Cânula ou cateter nasal: Dispositivo adequado para crianças que requerem baixas concentrações de oxigênio suplementar. A concentração de oxigênio fornecida depende da frequência respiratória, do esforço e do tamanho corporal; quanto menor a criança, maior a quantidade de oxigênio fornecida relativa ao fluxo. A concentração de oxigênio também depende de outros fatores, como a resistência nasal e de orofaringe, o volume corrente, o fluxo inspiratório e o tamanho da nasofaringe. $\mathrm{O}$ fluxo máximo de $\mathrm{O}_{2}$ utilizado por este dispositivo é de $4 \mathrm{~L} / \mathrm{min}$; fluxos maiores podem provocar irritação da nasofaringe. ${ }^{2}$

\section{Sistemas de alto fluxo:}

- Tenda facial: É um compartimento plástico flexível que pode ser mais tolerado do que a másca- ra facial, mesmo com altos fluxos de oxigênio (10 a $15 \mathrm{~L} / \mathrm{min}$ ). As concentrações de oxigênio, porém, não ultrapassam $40 \%$. Uma das vantagens desta tenda é que ela permite o acesso à aspiração de vias aéreas sem interrupção do fluxo.

- Capacete ou capuz de oxigênio: Invólucro de plástico transparente que abrange a cabeça do paciente. Bem tolerado em lactentes pequenos abaixo de 1 ano e permite fácil acesso ao tronco e às extremidades do paciente. Pode-se também controlar a concentração de gás inspirado, sua temperatura e umidade. Fluxos de $\mathrm{O}_{2}$ de 10-15 $\mathrm{L} / \mathrm{min}$ fornecem 80 - $90 \%$ de concentração de oxigênio. $^{2}$

- Tenda de oxigênio: Invólucro de plástico transparente que envolve a parte superior do corpo da criança. Mesmo com fluxos de $\mathrm{O}_{2}$ elevados, acima de $10 \mathrm{~L} / \mathrm{min}$, só consegue fornecer $50 \%$ de concentração de oxigênio, pois há entrada de ar pela abertura da tenda. Também tem a desvantagem de limitar o acesso ao tórax do paciente e, se utilizar umidificação, a névoa produzida pode impedir a observação do paciente. ${ }^{2}$

- Máscara com reinalação parcial: Consiste em uma máscara com uma bolsa reservatório. Com fluxos de $\mathrm{O}_{2}$ de $10-12 \mathrm{~L} / \mathrm{min}$ fornece concentração inspirada de 50-60\% de oxigênio, pois durante a exalação, uma parte do ar exalado penetra na bolsa reservatório misturando-se com o oxigênio. ${ }^{2}$

- Máscara não reinalante: Consiste em uma máscara com uma bolsa reservatório e duas válvulas: Uma válvula é incorporada em um ou ambos os orifícios de exalação para evitar a entrada de ar ambiente durante a inspiração, e a outra válvula localiza-se entre a bolsa reservatório e a máscara para evitar fluxo de ar exalado para dentro do reservatório. Assim, uma fração inspirada de oxigênio de $95-100 \%$ pode ser atingida com taxa de fluxo de $\mathrm{O}_{2}$ de $10-15 \mathrm{~L} / \mathrm{min}$ e o uso de máscara facial bem acoplada à face do paciente. ${ }^{2}$

- Máscara de Venturi: É um sistema capaz de fornecer concentrações baixas a moderadas de oxigênio inspirado (25\%-50\%). Há um dispositivo na máscara que cria uma pressão subatmosférica e permite a entrada de uma quantidade específica de ar ambiente junto com o $\mathrm{O}_{2}$. Devemse utilizar os dispositivos adequados e os fluxos de oxigênio indicados de acordo com a concentração de oxigênio desejada. 
- Ventilação assistida: Se a ventilação do paciente não for efetiva, com movimentos insuficientes e sons respiratórios inadequados, mesmo com as vias aéreas pérvias, deve-se proceder à ventilação assistida. Em situações de emergência, a ventilação com bolsa e máscara é o tratamento inicial de escolha.

- Ventilação com bolsa-máscara: Permite ventilar e oxigenar o paciente; pode ser realizada em pacientes com cânula orofaríngea ou nasofaríngea, e naqueles que não necessitam de nenhum dispositivo para manter as vias aéreas pérvias. ${ }^{3}$

- Técnica de ventilação com bolsa-máscara: Qualquer pessoa que provê cuidado pré-hospitalar, intra-hospitalar e durante o transporte deve estar apta a fornecer ventilação e oxigenação adequada com bolsa-máscara. Inicialmente, realiza-se a abertura das vias aéreas, coloca-se a máscara na face, fornecendo o volume corrente necessário para o tórax expandir. A técnica para abrir as vias aéreas e ajustar a máscara na face é chamada de técnica do "C e E". O terceiro, o quarto e o quinto dedos de uma mão (formando um E) são posicionados ao longo da mandíbula elevando-a para frente e para cima; esta elevação deve ser feita cautelosamente nos pacientes com suspeita de trauma cervical. Ao mesmo tempo, o polegar e o segundo dedo da mesma mão mantêm a máscara sobre a face da criança (formando um C) (Figura 5). Deve-se evitar exercer pressão abaixo do queixo, pois pode causar compressão e obstrução das vias aéreas. Podem ser necessárias duas pessoas para a ventilação com bolsa-máscara, caso se opte por fazer a técnica do "C e E" utilizando as duas mãos. A velocidade da ventilação será de 12-20 movimentos por minuto, se a criança tiver ritmo cardíaco com alguma perfusão. Durante a ventilação, pode ser necessário mover o pescoço gentilmente para trás ou para frente, até atingir a posição ótima para a ventilação efetiva. Se apesar disto, não se conseguir ventilação efetiva, deve-se reposicionar a cabeça da criança, assegurando que a máscara esteja bem vedada sobre a face, elevando a mandíbula e fazse a aspiração das vias aéreas, se necessário. Durante a ventilação com máscara facial é comum ocorrer distensão gástrica, principalmente se houver obstrução parcial de vias aéreas, diminuição da complacência pulmonar ou pressão ventilatória excessiva. A distensão gástrica pode atrapalhar a ventilação; ela pode ser minimizada em pacientes inconscientes pelo aumento do tempo inspiratório, fornecimento de volume corrente suficiente para expandir os pulmões (evitando volumes excessivos) com frequência respiratória adequada para dar tempo suficiente para a exalação e por fim, pela aplicação de pressão sobre a cartilagem cricoide (Manobra de Sellick). Esta manobra, além de diminuir a distensão gástrica, evita regurgitação e aspiração do conteúdo gástrico, pois oclui o esôfago proximal pelo deslocamento posterior da cartilagem cricoide. ${ }^{3}$

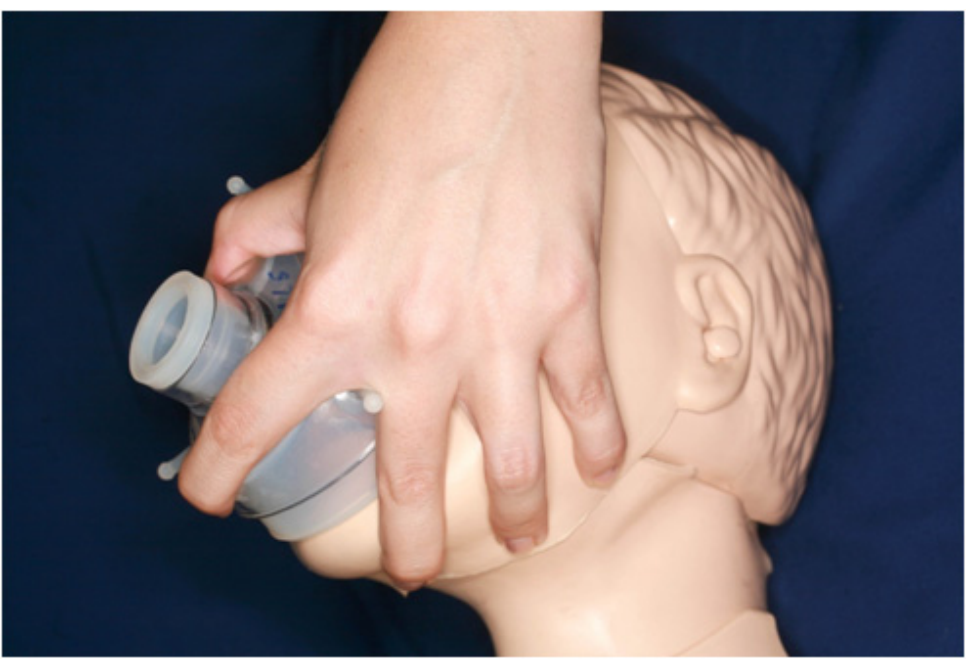

Figura 5: Técnica do "C e E".

- Escolha da máscara adequada: Idealmente, a máscara deve ser transparente para possibilitar a observação da cor dos lábios da criança, a condensação do ar (indica exalação) e a observação de regurgitação ou vômito, evitando a aspiração deste conteúdo para os pulmões. A máscara de tamanho adequado engloba a face desde a ponta do nariz até a cissura do queixo, devendo haver uma vedação hermética para que a concentração oxigênio inspirado não diminua e a ventilação seja eficaz. ${ }^{3}$

- Tipos de bolsa: Há bolsas autoinfláveis e fluxoinfláveis. Durante a ressuscitação, dá-se preferência às bolsas autoinfláveis, pois, embora as bolsas fluxo-infláveis sejam muito utilizadas em anestesia, elas requerem treinamento prévio na manipulação de suas válvulas. As bolsas autoinfláveis 
devem estar disponíveis em tamanhos adequados a todas as faixas etárias. As bolsas de 250 $\mathrm{mL}$, utilizadas para ventilação neonatal, podem ser inadequadas para manter um volume corrente efetivo em neonatos a termo e lactentes. Portanto, para recém-nascidos a termo, lactentes e crianças, a bolsa de ressuscitação deve ter capacidade mínima de 450-500 mL, mas independentemente do tamanho da bolsa, deve-se sempre observar a expansão torácica para fornecer somente a ventilação necessária. As bolsas autoinfláveis sem reservatório, quando acopladas a uma fonte de oxigênio, fornecem no máximo $40 \%$ de concentração de $\mathrm{O}_{2}$, enquanto que as bolsas com reservatório, com fluxo de oxigênio adequado para encher o reservatório (10-15 L/min), podem fornecer uma fração inspirada de $\mathrm{O}_{2}$ de até $100 \%$. Antes de iniciar a ventilação com bolsa-máscara, confirme se o oxigênio está conectado adequadamente à bolsa. ${ }^{2}$

- Efeitos adversos da ventilação com pressão positiva com bolsa-máscara: Volume corrente e pressão de vias aéreas excessivos podem reduzir o débito cardíaco por levar à diminuição do retorno venoso e ao aumento da pós-carga do coração direito, pela elevação da pressão intratorácica e distensão dos alvéolos. Além disso, pode haver escape de ar (barotrauma). Para minimizar o risco desta complicação, muitas bolsas possuem valvas de segurança limitadas à pressão $\left(35-45 \mathrm{~cm} \mathrm{H}_{2} \mathrm{O}\right){ }^{2}$

- Máscara laríngea: Dispositivo usado para assegurar as vias aéreas, que fornece um modo efetivo de ventilação e oxigenação. Consiste em um tubo, disponível em vários tamanhos, com projeção tipo máscara na extremidade distal com cuff que após sua introdução na faringe é inflado, vedando a hipofaringe e deixando a abertura distal do tubo sobre a abertura glótica, mantendo a via aérea pérvia. É usada em pacientes inconscientes e sua introdução é feita às cegas, até encontrar resistência. Pode ser utilizada em cirurgias de curta duração, em pacientes com trauma facial ou alteração anatômica das vias aéreas superiores e naqueles com intubação difícil, por ser de manejo mais fácil. O uso deste dispositivo é contraindicado nos pacientes com reflexo de vômito intacto, pois não protege as vias aéreas da aspiração de conteúdo gástrico. Durante parada cardíaca ou respiratória, pode ser alternativa efetiva para o restabelecimento das vias aéreas.
O uso da máscara laríngea durante o transporte de pacientes pode ser problemático, pois é difícil mantêla no local apropriado durante a movimentação. ${ }^{10}$

- Intubação traqueal: A ventilação através do tubo traqueal é o método mais efetivo e confiável de ventilação assistida, por vários motivos: Permite oferta de oxigênio e ventilação adequada sem insuflação do estômago; reduz aspiração pulmonar do conteúdo gástrico; facilita a aspiração de secreção e outras substâncias das vias aéreas; possibilita melhor controle do tempo inspiratório e dos picos de pressão, e a aplicação de pressão expiratória positiva final. ${ }^{9}$

\section{- Indicações de intubação traqueal:}

1. Controle inadequado da ventilação pelo sistema nervoso central.

2. Presença de obstrução funcional ou anatômica grave das vias aéreas.

3. Perda dos reflexos de proteção das vias aéreas.

4. Trabalho respiratório excessivo levando à fadiga e insuficiência respiratória.

5. Necessidade de alto pico de pressão inspiratória para manter as trocas gasosas.

6. Necessidade de proteção das vias aéreas.

- Tubo traqueal: Deve ser estéril, descartável e feito de cloreto de polivinil, um material translúcido e radiopaco. Na extremidade distal do tubo pode haver um orifício na parede lateral, chamado de olho de Murphy, que serve para reduzir o risco de atelectasia do lobo superior direito e a probabilidade de obstrução completa do tubo, caso a abertura da extremidade seja ocluída. O tubo apresenta marcas em centímetros que servem como ponto de referência durante a sua colocação e facilitam a detecção de possíveis deslocamentos do tubo; pode haver também uma marca para a corda vocal. Existem tubos com e sem cuff. Usualmente, eram utilizados tubos sem cuff para crianças até 10 anos, pois até esta idade, a criança apresenta um estreitamento anatômico no nível do anel cricoide, provendo, desta forma, um cuff funcional. Atualmente, pode-se utilizar cânula com cuff em todas as idades, principalmente em crianças que necessitem de altas pressões inspiratórias devido à baixa complacência pulmonar (p. ex. , síndrome do desconforto respiratório agudo) ou alta resistência de vias aéreas (p. ex. , asma). Ao insuflar o cuff, que é um mecanismo de alto volu- 
me com baixa pressão, deve-se respeitar a pressão de perfusão da mucosa traqueal $(25-35 \mathrm{~mm}$ $\mathrm{Hg}$ ), tomando o cuidado de evitar que a pressão fique baixa demais, a ponto de permitir escape de ar excessivo. Portanto, a pressão de insuflação deve ficar em torno de 20-30 mm Hg; o ideal é que se monitore esta pressão com aparelho adequado (cufômetro). A intubação com tubo traqueal, com ou sem cuff, deve permitir escape de gás mínimo, audível quando a ventilação é realizada com uma pressão de 20-30 cm de $\mathrm{H}_{2} \mathrm{O}$. A ausência completa de escape pode indicar que o tubo é muito grande, o cuff está excessivamente inflado ou há laringoespasmo ao redor do tubo. Essas condições podem causar pressão excessiva na superfície interna da traqueia; portanto, tão logo seja possível, deve-se substituir o tubo muito gran- de ou reduzir a pressão do cuff para minimizar o risco de trauma das vias aéreas. ${ }^{3,9}$

- Tamanho do tubo traqueal: O tamanho adequado do tubo varia de acordo com a idade. Em recém-nascidos prematuros, pode-se usar cânulas com diâmetro interno de $2 \mathrm{~mm}, 2,5 \mathrm{~mm}$ ou até de 3,0 mm. Em recém-nascidos a termo, utilizamse cânulas com diâmetro interno de 3 ou $3,5 \mathrm{~mm}$, e em crianças com 1 ano, 4 ou 4,5 mm. Em crianças maiores de 2 anos, o diâmetro interno do tubo (em $\mathrm{mm}$ ) pode ser calculado segundo as Equações 9 e 10. Embora seja um método de medida grosseiro e de pouca precisão, pode-se estimar o diâmetro interno do tubo comparando-o ao diâmetro do quinto dedo da mão do paciente. Os tamanhos de cânula e de sonda de aspiração de acordo com a faixa etária estão na Tabela $3 .{ }^{11}$

Diâmetro interno (cânula sem cuff) $(\mathrm{mm})=($ Idade em anos/ 4) +4 (Equação 9)

Diâmetro interno (cânula com cuff) $(\mathrm{mm})=($ Idade em anos/ 4) + 3,5 (Equação 10$)$

\section{Tabela 3}

Tamanhos de tubo traqueal e de aspiração pediátricos

\begin{tabular}{|c|c|c|}
\hline Tamanho aproximado para idade (peso) & $\begin{array}{c}\text { Diâmetro interno do } \\
\text { tubo traqueal (mm) }\end{array}$ & $\begin{array}{c}\text { Tamanho do cateter } \\
\text { de aspiração }(\mathrm{F})\end{array}$ \\
\hline Bebês prematuros $(<1$ kg) & 2,5 & 5 \\
\hline Bebês prematuros (1-2 kg) & 3,0 & 5 ou 6 \\
\hline Bebês prematuros $(2-3 \mathrm{~kg})$ & 3,0 a 3,5 & 6 ou 8 \\
\hline 0 mês a 1 ano $(3-10 \mathrm{~kg})$ & 3,5 a 4,0 & 8 \\
\hline 1 ano/ criança pequena $(10-13 \mathrm{~kg})$ & 4,0 & 8 \\
\hline 3 anos/ criança (14-16 kg) & 4,5 & 8 ou 10 \\
\hline 5 anos/ criança (16-20 kg) & 5,0 & 10 \\
\hline 6 anos/ criança $(18-25 \mathrm{~kg})$ & 5,5 & 10 \\
\hline 8 anos/ crianças a adultos pequenos $(24-32 \mathrm{~kg})$ & 6,0 com cuff & 10 ou 12 \\
\hline 12 anos/adolescente $(32-54 \mathrm{~kg})$ & 6,5 com cuff & 12 \\
\hline 16 anos/ adulto $(>50 \mathrm{~kg})$ & 7,0 com $c u f f$ & 12 \\
\hline Mulher adulta & $7,0-8,0$ com $c$ uff & 12 ou 14 \\
\hline Homem adulto & 7,0-8,0 com cuff & 14 \\
\hline
\end{tabular}


- Profundidade de inserção da cânula traqueal: É importante para a ventilação adequada, pois se a cânula estiver muito profunda, pode haver ventilação seletiva para um pulmão, geralmente o lado direito, por apresentar o brônquio fonte mais retificado, e se pouco profunda, o paciente pode se extubar facilmente. A maioria dos tubos traqueais possui marcas que devem ficar na altura das cordas vocais, mas há fórmulas para estimar a profundidade de inserção da cânula; a mais simples é 3 vezes o diâmetro interno da cânula (p. ex., o tubo de 5,0 $\mathrm{mm}$ deve ser inserido $15 \mathrm{~cm}$ ). Para recém-nascidos prematuros, podese usar outra regra: 6 + peso da criança, independentemente do número da cânula (p. ex. , criança de $1 \mathrm{~kg}$, inserção de $7 \mathrm{~cm}$ ). ${ }^{3}$

- Laringoscópio: Consiste em um cabo com pilhas e uma lâmina com uma fonte de luz. A lâmina é usada para expor a glote pelo deslocamento lateral da língua. Em posicionamento adequado, possibilita uma linha visual reta através da boca e da faringe até a laringe, permitindo que se passe o tubo traqueal. Existem lâminas de diversos tamanhos e a escolha certa para cada paciente deve ser baseada na medida entre a rima labial e o ângulo da mandíbula. ${ }^{3}$

- Preparação para intubação: Antes de intubar, deve-se permeabilizar as vias aéreas e fornecer oxigênio por máscara, se o paciente estiver respirando espontaneamente; caso contrário, se o paciente não estiver respirando ou sua respiração não for efetiva, deve-se iniciar ventilação com bolsa-valva e máscara antes da intubação, seguindo-se os passos abaixo: ${ }^{3}$

1. Monitorar a frequência respiratória e a saturação de oxigênio antes de tentar intubar. Nos pacientes em parada cardíaca ou insuficiência cardiopulmonar, não perder tempo na monitorização, pois estas situações não geram pulsos detectáveis.

2. Verificar o equipamento de intubação.

3. Usar precauções universais para reduzir riscos de infecção.

\section{- Equipamento de intubação:}

1. Monitor cardiorrespiratório e oxímetro de pulso.

2. Dispositivos para aspiração de grande calibre.

3. Ressuscitadores manuais e fonte de oxigênio.
4. Estilete (fio guia) para aumentar a rigidez do tubo traqueal e ajudar a guiá-lo através das cordas vocais; cuidado para não ultrapassar a ponta do estilete além da extremidade distal do tubo.

5. Três tamanhos de tubo, o estimado pela fórmula, um de menor calibre e outro de maior calibre.

6. Lâmina e cabo de laringoscópio com luzes funcionando.

7. Fitas, cadarços ou esparadrapo para fixar o tubo, ou fixadores apropriados.

8. Cateter de aspiração do tubo traqueal.

9. Detector de $\mathrm{CO}_{2}$ (capnógrafo).

- Técnica de intubação: A intubação nas crianças é mais difícil que nos adultos, por vários fatores: 1) A laringe tem posição posterior e mais cefálica, fazendo com que a epiglote tenha um ângulo agudo em relação à base da língua, dificultando sua visualização; por isso, lâminas retas são geralmente mais úteis do que as curvas para criar um plano visual direto da boca até a glote, principalmente em lactentes; 2) dificuldade de controlar a posição da língua com laringoscópio, por ela ser relativamente maior, havendo menor espaço para comprimi-la anteriormente; 3 ) a epiglote é mais longa, flexível, estreita e angulada, dificultando seu controle com o laringoscópio; 4) facilidade de entrada do tubo no esôfago ou de se prender na comissura anterior da corda vocal. Para visualização adequada da glote, os eixos da boca, faringe e traqueia devem estar alinhados. Utilizase a estabilização manual para manter a posição neutra. Em crianças sem suspeita de trauma cervical, posiciona-se a cabeça alinhando o meato auditivo à parte anterior do ombro, como referido anteriormente. Após o posicionamento da criança, segura-se o cabo do laringoscópio com a mão esquerda e introduz-se a lâmina dentro da boca, na linha média, seguindo o contorno natural da faringe até a base da língua. Uma vez que a ponta da lâmina esteja na base da língua e com a epiglote visualizada, move-se a extremidade proximal da lâmina para o lado direito da boca e depois, arrasta-se a língua em direção à linha média para obter seu controle. Pode-se usar a lâmina reta ou a curva; idealmente, a ponta da primeira serve para levantar a epiglote e visualizar a abertura glótica, já a lâmina curva é intro- 
duzida na valécula para deslocar a língua anteriormente. Após a introdução da lâmina no local apropriado, faz-se a tração do cabo para cima para deslocar a base da língua e a epiglote anteriormente, expondo a glote (Figura 6). Não deve ser feito movimento de báscula ou alavanca e a gengiva e os dentes não devem servir como ponto de apoio para a lâmina, pois estes movimentos podem danificar os dentes, traumatizar a gengiva e reduzir a capacidade de visualização da laringe. As tentativas de intubação devem ser breves; tentativas que duram mais de 30 segundos podem produzir hipoxemia profunda, especialmente nos lactentes, cujas reservas de oxigênio são menores. Se hipoxemia significativa, cianose, palidez ou bradicardia ocorrerem, a tentativa de intubação deve ser interrompida e o paciente deve ser ventilado imediatamente com oxigênio a 100\%, utilizando bolsa-valva e máscara até melhora da saturação e da frequência cardíaca. Em situações em que o paciente estiver instável e for difícil ventilar ou oxigenar com bolsa-valva e máscara, é preferível que se tente novamente a intubação e esta tentativa deve ser feita pelo profissional mais habilitado. Nas situações de emergência, a intubação orotraqueal é preferida, pois pode ser feita com maior rapidez que a nasotraqueal., 2,6

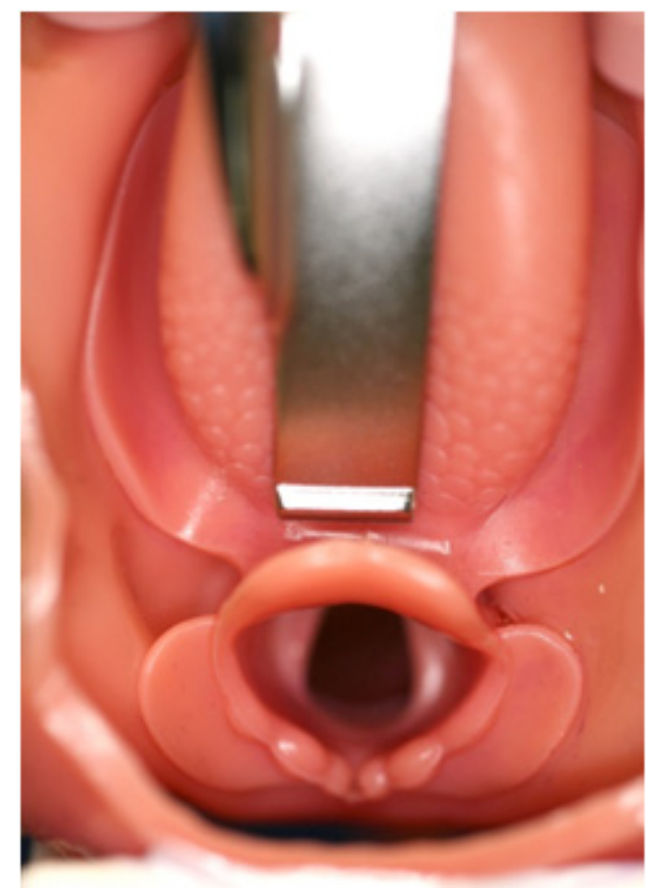

Figura 6: Visão da glote exposta pela colocação da lâmina curva do laringoscópio na valécula.
- Confirmação da intubação: A confirmação inicial da intubação é a visualização da passagem do tubo através das cordas vocais. Depois da introdução do tubo traqueal e do início da ventilação com pressão positiva, é feita avaliação clínica para confirmação da posição apropriada do tubo, que inclui: 1. Observação da expansão torácica; 2. ausculta do murmúrio vesicular nos campos pulmonares, axilas e ápice bilaterais (os achados do exame pré-intubação devem servir de base para comparação depois da intubação); 3. ausculta da região epigástrica, (se o tubo estiver na traqueia, haverá ausência de murmúrio vesicular); 4. detecção do $\mathrm{CO}_{2}$ exalado. A avaliação clínica somente pode não ser suficiente para a confirmação da intubação e, portanto, a detecção do $\mathrm{CO}_{2}$ exalado deve ser usada como confirmação primária da intubação. Em pacientes com ritmo cardíaco com perfusão e peso $>2 \mathrm{~kg}$, detecta-se a presença de $\mathrm{CO}_{2}$ após seis ventilações manuais. Recomenda-se a realização de seis ventilações, objetivando eliminar o $\mathrm{CO}_{2}$ que possa estar presente no estômago e no esôfago. Depois de seis ventilações, $\mathrm{o} \mathrm{CO}_{2}$ detectado deve ser considerado como proveniente da traqueia, pois há concentração insignificante de $\mathrm{CO}_{2}$ no ar ou no estômago. Apesar de a detecção de $\mathrm{CO}_{2}$ exalado em pacientes com ritmo cardíaco com perfusão ser método sensível e específico para confirmar a localização do tubo na traqueia, não é confiável para confirmar a intubação em pacientes com parada cardíaca. Nestes, a ausência de $\mathrm{CO}_{2}$ exalado não indica que o tubo esteja em posição esofágica, pois estes pacientes têm fluxo sanguíneo pulmonar limitado e, portanto, mesmo que o tubo esteja na traqueia pode ser que o $\mathrm{CO}_{2}$ não seja detectado. Além da parada cardíaca, outras condições que causam fluxo muito baixo de $\mathrm{CO}_{2}$ expirado podem produzir resultados enganosos, como por exemplo, em adultos com asma grave e edema pulmonar, pode haver eliminação de $\mathrm{CO}_{2}$ prejudicada, com resultado falso negativo. Pode haver também contaminação do detector colorimétrico com ácidos ou fármacos ácidos, como a epinefrina administrada por via intratraqueal. Deve-se suspeitar desta contaminação se a cor permanecer amarela em todo o ciclo respiratório. Outras formas de confirmar a intubação são pela observação de vapor d'água no tubo durante a exalação (é sugestiva, mas não confirma a intubação); 
melhora da saturação de oxigênio ou sua permanência em níveis adequados após a intubação, exceto se houver comprometimento pulmonar importante; ausência de distensão epigástrica durante a ventilação - caso ocorra, deve-se suspeitar de intubação esofágica. Se persistir alguma dúvida sobre a posição do tubo, deve-se usar o laringoscópio para confirmar sua posição através da visualização direta. Após confirmação da intubação, fixa-se a cânula, e depois confirma-se a posição correta do tubo na traqueia pela radiografia de tórax (o local adequado é pelo menos 1 $\mathrm{cm}$ acima da carina ou na altura da segunda ou terceira vértebra torácica). ${ }^{3}$

- Causas de deterioração aguda de pacientes intubados: Os pacientes intubados estão em risco constante de apresentar problemas que podem resultar em perda potencialmente fatal da função das vias aéreas. Para detectar estes problemas precocemente e solucioná-los prontamente, o paciente deve estar monitorizado com oximetria de pulso e monitorização cardíaca e do $\mathrm{CO}_{2}$ exalado. Quando há desenvolvimento súbito de desconforto respiratório e/ou cianose, devese avaliar rapidamente se a troca dos gases e a oxigenação estão adequadas, pela observação da expansibilidade torácica, monitorização não invasiva (citada acima) e ausculta do tórax. Esta avaliação determinará a urgência da conduta a ser tomada. As possíveis causas de deterioração súbita podem ser recordadas pelo método mnemônico DOPE: D = Deslocamento do tubo ocasionado pela extubação ou pela inserção do tubo além da carina, fazendo com que a intubação fique seletiva em algum brônquio; $\mathbf{O}=\mathbf{O b s t r u c ̧ a ̃ o ~}$ por secreção, sangue, corpo estranho ou torção do tubo; $\mathbf{P}=$ Pneumotórax $\mathbf{E}=$ falha de Equipamento, tais como, desconexão do fornecimento de oxigênio, escape de ar do ventilador ou do circuito, falha mecânica ou do fornecimento de energia. Na prática, para detectar estes problemas e solucioná-los imediatamente, deve-se proceder da seguinte forma: Se o paciente estiver acoplado ao respirador, deve-se colocá-lo na ventilação manual com bolsa-valva; deste modo, pode-se descartar a falha de equipamento e avaliar se a complacência e a resistência pulmonar do paciente estão alteradas. Se a complacência estiver diminuída e a resistência aumentada, mais força deverá ser aplicada na bolsa para ventilar o paci- ente. Lembrar que uma das causas de aumento da resistência à ventilação manual com bolsavalva e ausência de expansão torácica é a obstrução do tubo; neste caso, deve-se proceder à aspiração da cânula ou à troca do tubo, caso a obstrução seja extensa. Outra causa de ausência de expansão torácica é o deslocamento do tubo e a extubação do paciente. Assimetria da expansão torácica e da ausculta do murmúrio vesicular, quando maiores à direita, sugerem intubação seletiva, pois a tendência natural da cânula é entrar no brônquio fonte direito, que é mais retificado que o esquerdo. Nestes casos, deve-se observar também a medida em que foi fixado o tubo, para verificar se o mesmo pode ter se deslocado. Caso persistam dúvidas se o paciente está ou não intubado, faz-se a observação direta com laringoscópio e, se necessário, reintuba-se imediatamente o paciente ou reposiciona-se o tubo no local correto, de acordo com a medida da profundidade de inserção do tubo inferida pela fórmula (3 x diâmetro do tubo), verificando a simetria da ausculta pulmonar. Outra possibilidade de deterioração súbita em paciente intubado que evolui com assimetria da ausculta pulmonar é o pneumotórax hipertensivo. Clinicamente, este diagnóstico pode ser suspeitado quando há diminuição do murmúrio vesicular e timpanismo à percussão do tórax no lado acometido; além disso, pode haver estase jugular, desvio de traqueia e sinais de baixo débito cardíaco devido à obstrução mecânica ao fluxo dos vasos. A conduta de descompressão deve ser feita rapidamente, assim que o pneumotórax seja detectado clinicamente. Para a descompressão, utiliza-se agulha número 20, conectada a uma seringa com selo d'água, introduzindo-a no segundo espaço intercostal, na linha hemiclavicular, na borda superior da costela inferior (terceira costela); se houver ar, o líquido dentro da seringa borbulhará. Logo após a confirmação de pneumotórax com a punção, deve-se proceder à drenagem torácica. ${ }^{3}$

\section{Casos clínicos}

\section{Caso 1}

Criança de 6 meses, chega ao pronto atendimento com história de febre de $38^{\circ} \mathrm{C}$ há 3 dias, 1-2 picos por dia, que cede com antitérmico, coriza nasal 
hialina, tosse rouca (como um latido de cachorro), e presença de sons inspiratórios. Evoluiu com desconforto respiratório com piora progressiva, e hoje se apresenta com cansaço mais acentuado, sendo trazida para atendimento.

Cenário 1. Inicial: Ao exame, a criança encontra-se agitada, com cianose central, retração de fúrcula esternal à inspiração, retração intercostal e estridor inspiratório audível sem estetoscópio. A frequência respiratória é de 68 ipm, a frequência cardíaca de $160 \mathrm{bpm}$, com pulsos periféricos e centrais palpáveis e cheios, tempo de enchimento capilar $2 \mathrm{seg}$, pressão arterial 90/50 mm Hg. A oximetria de pulso revela saturação de $\mathrm{O}_{2}$ de $80 \%$.

\section{Pergunta-se: Quais são o diagnóstico e a con- duta?}

Resposta: O diagnóstico é de insuficiência respiratória aguda secundária à obstrução de vias aéreas superiores (com desconforto respiratório na fase inspiratória), tendo como causa provável a laringite viral (crupe). A conduta adequada é: 1) Permeabilizar as vias aéreas pelo posicionamento da cabeça com colocação de coxim sob os ombros, alinhando o meato auditivo com a parte anterior do ombro, e aspirar as vias aéreas com delicadeza, pois a aspiração pode provocar laringoespasmo, piorando a obstrução provocada pelo edema adjacente à laringe. 2) Ofertar oxigênio. Como neste caso, a criança ainda mantém um drive respiratório efetivo, com frequência e esforço respiratório adequados, pode ser ofertado $\mathrm{O}_{2}$ com máscara não reinalante com fluxo de oxigênio de 10-15 L/min. Após cada procedimento, deve-se reavaliar a criança.

Cenário 2. Após reavaliação: A reavaliação após permeabilização de vias aéreas e oferta de oxigênio revela que a criança está sem cianose, com saturação de $\mathrm{O}_{2}$ de $94 \%$, mantém estridor com retração de fúrcula, frequência cardíaca de $120 \mathrm{bpm}$, pressão arterial de 90/50 mm Hg, tempo de enchimento capilar de 2 segundos, pulsos periféricos e centrais cheios, mas quando ela chora ou se agita, a saturação de $\mathrm{O}_{2}$ cai para $89 \%$.

\section{Pergunta-se: Qual é a conduta?}

Resposta: É necessário acalmar a criança, deixando-a em posição confortável, de preferência no colo da mãe, pois quando ocorre agitação, o fluxo de ar se torna mais turbulento, dificultando a sua passagem (a resistência à passagem de ar com fluxo turbu- lento é inversamente proporcional à quinta potência do raio da via aérea). Além disso, deve-se iniciar a terapêutica específica para a doença de base. No caso, usa-se aerossol com adrenalina $0,5 \mathrm{~mL} / \mathrm{kg} /$ dose (máx. $5 \mathrm{~mL}$ ) de $\mathrm{h} / \mathrm{h}$ ou a cada $2 \mathrm{~h}$, e corticosteroide EV ou IM (dexametasona $0,15 \mathrm{mg} / \mathrm{kg} /$ dose de $6 / 6 \mathrm{~h}$ ).

\section{Caso 2}

Criança de 5 anos, apresenta tosse há uma semana, inicialmente seca, que se tornou produtiva há 3 dias, acompanhada de febre alta de difícil controle com antitérmicos, além de perda do apetite e queda do estado geral, que vêm piorando progressivamente. Hoje a mãe notou que criança estava com muita dificuldade para respirar e a trouxe para atendimento.

Cenário 1. Inicial: Ao exame, a criança se encontra inconsciente, com cianose generalizada e dispneia importante, com respiração tipo "gasping", frequência respiratória de $8 \mathrm{ipm}$, frequência cardíaca de 150 bpm, pressão arterial de 110/ 60 mm Hg, pulsos periféricos e centrais cheios, tempo de enchimento capilar de 2 segundos. A ausculta pulmonar revela diminuição do murmúrio vesicular à direita, com estertores crepitantes na base. A oximetria de pulso mostra saturação de $\mathrm{O}_{2}$ de $70 \%$.

\section{Quais são o diagnóstico e a conduta?}

Resposta: O diagnóstico é insuficiência respiratória aguda em iminência de parada respiratória (com respiração agônica tipo "gasping" e bradipneia), devido à provável pneumonia bacteriana. A conduta inicial consiste em posicionar a cabeça da criança pela colocação de coxim sob o occipício, aspirar as vias aéreas e, logo em seguida, iniciar ventilação com pressão positiva com bolsa-valva e máscara. Como a criança possui perfusão sanguínea no pulmão (ou seja, não está em parada cardíaca), deve-se ventilar com frequência de 12-20 movimentos por minuto, e se necessário, aumentar a frequência da ventilação conforme a saturação de $\mathrm{O}_{2}$ na oximetria de pulso.

Cenário 2. Após reavaliação: A criança apresenta expansibilidade torácica adequada à ventilação assistida com bolsa-valva e máscara, mantendo saturação de $\mathrm{O}_{2}$ de $95 \%$, mas está entregue à ventilação manual.

\section{Pergunta-se: Qual é a conduta agora?}

Resposta: O próximo passo é a intubação orotraqueal, com cânula número 5 (Idade/4 + 4 5), fixada em 15 ( 3 x diâmetro interno da cânula $=15)$. 
Cenário 3. Após segunda reavaliação: Após intubação, a criança mantém saturação de 97\%, com frequência cardíaca de 120 bpm, tempo de enchimento capilar 2 segundos, pressão arterial 110/ $55 \mathrm{~mm} \mathrm{Hg}$, pulsos periféricos e centrais palpáveis e cheios. É colocada em ventilação mecânica e subitamente, após alguns minutos, apresenta queda da saturação de $\mathrm{O}_{2}$ para $70 \%$.

\section{Pergunta-se: $\mathrm{O}$ que deve ser feito?}

Resposta: As causas de deterioração aguda em pacientes intubados devem ser investigadas, segundo a regra DOPE: $\mathbf{D}=$ Deslocamento do tubo ocasionado por extubação ou intubação seletiva; $\mathbf{O}=\mathbf{O b s t r u c ̧ a ̃ o ; ~}$ $\mathbf{P}=$ Pneumotórax $; \mathbf{E}=$ falha de Equipamento. Inicialmente, visando eliminar a causa relacionada à falha de equipamento, desconecta-se o paciente do respirador, ventilando-o manualmente com bolsa-valva. Ao mesmo tempo, durante a ventilação manual, pode-se sentir se há aumento da resistência (que pode sugerir obstrução do tubo) ou diminuição da complacência pulmonar secundária à piora da doença de base. Verifica-se a posição do tubo e a expansibilidade torácica, procurando descartar a possibilidade de extubação (tubo pouco introduzido com ausência de expansão torácica) ou de intubação seletiva (tubo introduzido mais do que o recomendado $(15 \mathrm{~cm})$, com expansibilidade torácica assimétrica, geralmente maior à direita). Além disso, realiza-se o exame físico, com ausculta pulmonar e percussão torácica, à procura de possível pneumotórax. Caso a ausculta do murmúrio vesicular esteja diminuída e haja timpanismo à percussão, com diminuição da expansibilidade torácica no lado afetado, faz-se uma punção de prova com agulha número 20 conectada a uma seringa com selo d'água $(\sim 5 \mathrm{~mL})$, introduzindo-a perpendicularmente na linha hemiclavicular, na borda superior da terceira costela, com aspiração simultânea. Havendo saída de ar, desconectase a seringa da agulha, deixando-a inserida no local, enquanto se providencia a drenagem torácica.

\begin{abstract}
This paper presents a review of the definition, pathophysiology and management of respiratory distress and failure in children, and emphasizes the most appropriate devices for oxygen delivery. Children are more susceptible to severe respiratory problems, which are leading causes of pediatric emergency room demand. Prompt recognition and effective management of respiratory problems are essential to improve outcome of these patients.
\end{abstract}

Keywords: Respiratory Failure. Child. Emergency Service, Hospital. Oxygen Delivery Devices.

\section{Referências Bibliográficas}

1. Piva JP, Garcia PC, Santana JC, Barreto SS. [Respiratory failure in the child]. J Pediatr (Rio J) 1998; 74 Suppl 1: S99-S112.

2. American Heart Association, PALS - Pediatric Advanced Life Support - Provider Manual. 2002.

3. American Heart Association, PALS - Pediatric Advanced Life Support - Provider Manual. 2006.

4. Levy RJ, Helfaer MA. Pediatric airway issues. Crit Care Clin 2000; 16:489-504.

5. Fisher CJJr. Physiology of respiration. Emerg Med Clin North Am 1983; 1: 223-39.

6. Santillanes G, Gausche-Hill M. Pediatric airway management. Emerg Med Clin North Am 2008; 26: 961-75.

7. Piva JP, Canani SF, Pitrez PM, Stein RT. [ Severe acute asthma in the child]. J Pediatr (Rio J) 1998; 74 Suppl 1: S59-68.
8. Sinex JE. Pulse oximetry: principles and limitations. Am J Emerg Med 1999; 17:59-67.

9. Holm-Knudsen RJ, Rasmussen LS. Paediatric airway management: basic aspects. Acta Anaesthesiol Scand 2009; 53: 1-9.

10. Hoffman RJ, Parwani V, Hahn IH. Experienced emergency medicine physicians cannot safely inflate or estimate endotracheal tube cuff pressure using standard techniques. Am J Emerg Med 2006; 24:139-43.

11. Kleinman ME, de Caen AR, Chameides L, Atkins DL, Berg RA, Berg MD, et al. Part 10: Pediatric basic and advanced life support: 2010 International Consensus on Cardiopulmonary Resuscitation and Emergency Cardiovascular Care Science With Treatment Recommendations. Circulation 2010; 122 (Suppl 2): S466-515. 